\title{
Heart Failure With Preserved Ejection Fraction and Adipose Tissue: A Story of Two Tales
}

\author{
Albin $\mathrm{Oh}^{1 \dagger}$, Ross Okazaki ${ }^{2+}$, Flora Sam ${ }^{1,2,3,4}$ and Maria Valero-Muñoz ${ }^{2,4 *}$ \\ ${ }^{1}$ Evans Department of Medicine, Boston Medical Center, Boston, MA, United States, ${ }^{2}$ Boston University School of Medicine, \\ Boston, MA, United States, ${ }^{3}$ Section of Cardiovascular Medicine, Boston Medical Center, Boston, MA, United States, \\ ${ }^{4}$ Whitaker Cardiovascular Institute, Boston University School of Medicine, Boston, MA, United States
}

\section{OPEN ACCESS}

Edited by:

Jose Javier Fuster,

Centro Nacional de Investigaciones

Cardiovasculares (CNIC), Spain

Reviewed by:

Petra Kienesberger,

Dalhousie University, Canada

Salvatore Carbone

Virginia Commonwealth University,

United States

Sergio Martinez Hervas,

University of Valencia, Spain Rei Shibata,

Nagoya University Hospital, Japan

${ }^{*}$ Correspondence: Maria Valero-Muñoz mvalerom@bu.edu

tThese authors have contributed equally to this work

Specialty section:

This article was submitted to Cardiovascular Metabolism,

a section of the journa

Frontiers in Cardiovascular Medicine

Received: 22 May 2019

Accepted: 22 July 2019

Published: 02 August 2019

Citation:

Oh A, Okazaki R, Sam F and Valero-Muñoz M (2019) Heart Failure With Preserved Ejection Fraction and Adipose Tissue: A Story of Two Tales.

Front. Cardiovasc. Med. 6:110 doi: 10.3389/fCvm.2019.00110
Heart failure with preserved ejection fraction (HFpEF) is characterized by signs and symptoms of heart failure in the presence of a normal left ventricular ejection fraction. Although it accounts for up to 50\% of all clinical presentations of heart failure, there are no evidence-based therapies for HFpEF to reduce morbidity and mortality. Additionally there is a lack of mechanistic understanding about the pathogenesis of HFpEF. HFpEF is associated with many comorbidities (such as obesity, hypertension, type 2 diabetes, atrial fibrillation, etc.) and is coupled with both cardiac and extra-cardiac abnormalities. Large outcome trials and registries reveal that being obese is a major risk factor for HFpEF. There is increasing focus on investigating the link between obesity and HFpEF, and the role that the adipose tissue and the heart, and the circulating milieu play in development and pathogenesis of HFpEF. This review discusses features of the obese-HFpEF phenotype and highlights proposed mechanisms implicated in the inter-tissue communication between adipose tissue and the heart in obesity-associated HFpEF.

Keywords: HFpEF, adipose tissue, obesity, natriuretic peptides, cardiac remodeling

\section{HEART FAILURE WITH PRESERVED EJECTION FRACTION (HFPEF): A NEW TERM FOR AN OLD DISEASE}

Heart failure (HF) is a clinical syndrome caused by structural and functional abnormalities in the heart that impair the ability of the ventricles to fill or eject blood. The cardinal manifestations of HF are breathlessness, dyspnea and fatigue, which may lead to limited effort tolerance; and fluid retention, thus resulting in pulmonary congestion and/or peripheral edema $(1,2)$. HF is a leading cause of morbidity and mortality both in the United States and worldwide. As of 2012, 5.8 million Americans had HF with the number of individuals with HF projected to continue to increase in the next 20 years (3-5).

Segregating patients with HF by left ventricular (LV) ejection fraction (EF) is an important phenotypic marker as it indicates unique pathophysiological mechanisms and thus subsequent responses to therapy (6-8). Patients with clinical HF and normal or preserved EF represent a phenotype that is different from those with reduced EF (HFrEF). HFpEF is due to the inability of the heart to fill with blood because it may be thick or stiff. HFpEF patients are often touted as elderly, predominantly female, obese, have long-standing hypertension, may have diabetes, and some degree of LV hypertrophy $(9,10)$. HFpEF was initially labeled as "diastolic HF" because impaired filling of the LV was thought to be the underlying etiology to differentiate it from "systolic HF" (HFrEF) (11). However, LV diastolic dysfunction is not unique to HFpEF and is also observed in patients with $\operatorname{HFrEF}(9,12)$. Similarly, "diastolic HF" patients may have some degree of impaired 
systolic function $(13,14)$. Thus, the term "diastolic" HF was abandoned and replaced by HFpEF. The definition of HFpEF moved away from a primary focus on echocardiographic evidence of diastolic dysfunction, and toward a definition inclusive of cardiac structural abnormalities resulting from high filling pressures, diastolic abnormalities, elevated biomarkers, and increased left heart filling pressures by invasive hemodynamic measurements in the setting of an EF $\geq 50 \%$ (15-17).

In contrast to HFrEF, there are no evidence-based therapies, to date, which have shown improved outcomes in HFpEF (2), likely because of the marked heterogeneity of the HFpEF syndrome $(16,18)$. It has been suggested that phenotyping patients into pathophysiologically homogeneous groups in clinical trials may result in better outcomes (19-21). Increased adiposity in obesity has been suggested to be a therapeutic target in HFpEF (22). This review, therefore, summarizes the current understanding of HFpEF in context of obesity, and how "crosstalk" exists between the heart and the adipose tissue in these two conditions.

\section{The Obese-HFpEF Phenotype}

Obesity has reached epidemic proportions worldwide and is a major comorbidity in HFpEF patients (23-25). The prevalence of being overweight and obese is as high as $84 \%$ in clinical trials, epidemiological studies and HF registries (26-28) and presently there are $>1.8$ million persons in the U.S. with an overweight or obesity-associated HFpEF phenotype (22). Earlier studies suggested that symptoms in obese HFpEF patients were simply related to excess body mass and not to cardiac abnormalities (29). However, recent disease paradigms have incorporated obesity into the pathophysiology of HFpEF (24). Obesity and related cardio-metabolic traits are also more strongly associated with the risk of future HFpEF rather than HFrEF (30), suggesting that obesity-associated HFpEF represents a distinct clinical phenotype within the broad spectrum of $\operatorname{HFpEF}(24,31)$. Studies from murine models have highlighted the relationship between obesity, diastolic dysfunction and HFpEF. Increased adiposity and metabolic alterations in obesity were associated with cardiac structural remodeling and diastolic dysfunction in mice and rats $(32,33)$, and have recently been described to induce HFpEF (34-38). These models are useful tools to investigate mechanisms linking obesity and HFpEF and to explore the use of potential therapies in this specific phenotype (39). However, there is no animal model that can completely mimic the human disease, partly because human HFpEF is heterogeneous and encompasses a broad range of signs, symptoms, and disease presentation (39). Thus, the paucity of highly characterized HFpEF animal models that reflect cardiopulmonary and metabolic changes seen in obesity associated-HFpEF in humans contributes to the lack of understanding of the mechanisms underlying HFpEF and the development of treatments.

\section{THE ADIPOSE TISSUE AND THE HEART CROSS-TALK IN HFPEF}

There is an increasing appreciation of the complex connection between the adipose tissue and the heart, which highlights the importance of the heart-adipose-axis in the pathogenesis of cardiovascular disease and specifically HF (40). However, the putative mechanisms that connect both tissues and link obesity and HF have not been fully elucidated $(23,41)$. It was long assumed that the burden of obesity in HF was a physical/mechanical one (42). Thus, hemodynamic alterations that result from excessive adipose accumulation in obese patients would have subsequent effects on cardiac morphology and ventricular function (43). Although volume overload plays a role in HF and specifically HFpEF, in recent years, the endocrine, metabolic and cellular signaling behind the obesity-related HFpEF phenotype has received much attention.

Current evidence supports the hypothesis that obesity-related HFpEF may result from adipokines imbalance, neprilysin overactivity and/or augmented mineralocorticoid signaling (44). Adipose tissue is a potent endocrine organ that synthesizes and secretes a number of adipose-specific cytokines, aka adipokines, such as leptin or adiponectin, which elicit a variety of local and systemic responses (45). Leptin originates mainly from subcutaneous adipose tissue (46) and circulating levels of leptin directly correlate with fat mass in both obese rodents and humans (40). Leptin plays an important role in the regulation of the sympathetic nervous system, affecting heart rate and blood pressure (47) and exert its effects by activating various mediators including the Janus kinases (JAK)/Signal Transducer and Activator of Transcription proteins (STAT), the phosphoinositide 3-kinase (PI3K)/ cGMP-dependent protein kinase $\mathrm{B}(\mathrm{PKB})$ and the $\mathrm{p} 38$ mitogen-activated protein kinase (p38-MAPK) pathways (48). Alterations in leptin signaling have deleterious effects in cardiac remodeling in pre-clinical models of obesity (33). Additionally, leptin is a major stimulus for the production of aldosterone in obesity $(49,50)$, and might be responsible for the exacerbated mineralocorticoid receptor signaling in obesity-related $\operatorname{HF}(51,52)$. In addition to aldosterone-mediated changes in cardiac structure, such as exacerbated cardiac remodeling $(53,54)$, increased leptin results in impaired calcium handling and impaired relaxation in the heart $(55,56)$. However, although the contribution of leptin to the genesis and progression of the obese-HFpEF phenotype has been speculated (42), there are no mechanistic or clinical evidences to support leptin's role in the HFpEF phenotype. In contrast to leptin, adiponectin levels are highest in lean subjects but decline as body mass increases (57). Adiponectin have multiple beneficial effects in the heart and the vasculature (45) and, not surprisingly, depressed levels in obesity are associated with inflammation and greater cardiovascular risk (58-60). Experimental evidence showed that adiponectin has anti-inflammatory properties (61) and modulates oxidative stress-induced autophagy (62) and cardiac remodeling (63). These beneficial effects of adiponectin have been linked to direct effects of this adipokine on the cellular in the heart and blood vessels. It has been postulated that the ability of adiponectin to attenuate cardiac hypertrophy and fibrosis is likely due to its ability to stimulate AMP-activated protein kinase (AMPK)-dependent and extracellular-signal-regulated kinase (ERK) signaling within cardiac myocytes and endothelial cells (63-65). However, although adiponectin levels are not predictive of HF development in humans (66), human studies 
indicate that elevated circulating adiponectin is associated with increased mortality in chronic HFrEF patients (67-69). These findings have been partly explained by the fact that adiponectin upregulation seems to be liked to cachexia and adiponectin raised levels may just reflect the hyper-catabolic state in severe HF $(70,71)$. This is consistent with the fact that overweight and obese HFrEF patients had normal levels of adiponectin (72). In contrast, circulating levels of adiponectin are markedly reduced in obese HFpEF patients, particularly in women (73), and it has been suggested that adiponectin may prevent some of the pathophysiologic mechanisms underlying the obese-HFpEF such as myocardial hypertrophy, cardiac fibrosis, oxidative stress, and inflammation $(44,60)$. The relationship of adiponectin to aldosterone appears to be polar opposite in HFpEF, as adiponectin deficiency in a preclinical model of hypertensionassociated HFpEF where aldosterone is elevated, exacerbated cardiac remodeling, diastolic dysfunction and pulmonary congestion (74); and adiponectin overexpression protected against the progression of HFpEF by regulating oxidative stress and modulating calcium-handling proteins, specifically cAMP-dependent protein kinase (PKA) phosphorylation of phospholamban (75).

Chronic, low-grade inflammation is also a hallmark of obese adipose tissue (76) and systemic metabolic inflammation, accompanied by an increased activity of the inducible nitric oxide synthase (iNOS) and augmented nitrosative stress, may play an important role in the pathophysiology of obesityassociated HFpEF (77). This is supported by the hypothesis that imbalance in the nitrate-nitrite-nitric oxide pathway plays a role both in the peripheral abnormalities that contribute to HFpEF, such as increased arterial stiffness and abnormalities in skeletal muscle fiber type and capillary density (78). Increased oxidative stress in the coronary microvascular endothelium due to decreased nitric oxide bioavailability and reduced cGMP dependent protein kinase (PKG) activity in cardiac myocytes, results in increased cardiac stiffening and hypertrophy (5) thus contributing to the cardiac abnormalities. Additionally, the clinical relevance of proinflammatory cytokines in obesityassociated HFpEF is being actively investigated, with promising targets including inflammasome, toll-like receptors, cytokines and macrophages $(79,80)$. Notably, interleukin 1 (IL-1) has been strongly associated with adverse cardiac remodeling and heart failure and strategies targeting the IL-1 pathway are currently undergoing clinical evaluation $(81,82)$.

\section{Obesity and Exercise Tolerance in HFpEF}

Decreased exercise tolerance is an early symptom of $\mathrm{HFpEF}$ and is a major determinant of prognosis and associates with a reduction in quality of life (83). Exercise capacity is defined as the rate of $\mathrm{O}_{2}$ consumption $\left(\mathrm{VO}_{2}\right)$ at peak exercise, and any factor that limits peak $\mathrm{VO}_{2}$, by impeding $\mathrm{O}_{2}$ delivery and/or utilization, can cause exercise intolerance (84). Although exercise intolerance in HFpEF was classically attributed to changes in cardiac output, new findings suggest that peripheral, non-cardiac factors play an important role in the limitations in exercise capacity in patients with HFpEF (85). Of these, obesity has been also proposed to be a major driver of exercise intolerance, independent of the effects of cardiac function (86). Interestingly, the pattern of regional adipose deposition, with increased intra-abdominal and intermuscular fat appear to associate with decreased peak $\mathrm{VO}_{2}$, and may thus be related to adverse consequences in exercise tolerance in HFpEF beyond total body adiposity (87).

It has been suggested that higher levels of exercise training may attenuate the increased risk of HF associated with obesity (88). Exercise, in addition to caloric restriction-induced weight loss, are the only interventions shown to improve exercise capacity outcome in HFpEF (89-92). Furthermore, a recent study demonstrated that exercise training improved not only exercise capacity but also body composition, with a reduction in total fat mass and thigh muscle/inter-muscular fat ratio, and with reduced inflammation and LV mass (92). Similarly, preclinical studies in obese HFpEF rats showed that exercise training improved exercise capacity (36). Further studies are warranted in order to investigate specific mechanisms involved.

\section{The Obesity Paradox}

Although obesity is linked to the development of HF (23) and associates with abnormal hemodynamics and adverse cardiac remodeling in HFpEF (93), in epidemiological studies mild to moderate overweight or obesity status (body mass index, BMI, of 30-34.9) was reported to have a protective effect in patients with HF $(94,95)$. This phenomenon was termed "the obesity paradox" and initially observed in small population studies $(96,97)$ and confirmed in large observational studies in both HFrEF and HFpEF patients $(26,98-101)$. However, other studies have not shown that the obesity paradox exists in HFpEF (102-104), and thus, the causal link between this scientific observation and its clinical implications are limited and remain hotly debated. Several hypotheses are proposed to explain the presence or absence of the obesity paradox $(105,106)$, and have been extensively reviewed (107-109).

\section{Cardiac Natriuretic Peptides and Obesity in HFpEF}

Cardiac natriuretic peptides are mainly released from the heart in response to myocardial stress and have a key role in cardiovascular homeostasis (110). There are three types of natriuretic peptides in humans, atrial natriuretic peptide (ANP), brain natriuretic peptide (BNP) and C-type natriuretic peptide (CNP). ANP and BNP are released from the atria and ventricles of the heart respectively and are the most physiologically active natriuretic peptides. In contrast, $\mathrm{CNP}$ is thought to act locally, as a paracrine/autocrine regulator, since it is cleared rapidly from the circulation and present at very low concentrations in plasma (111) with effects primarily on bone growth (112). ANP and BNP bind to two homodimeric receptors, natriuretic peptide active and clearance receptors (NPRA and NPRC respectively), which are expressed in many tissues, including white and brown adipose tissue (113). This broad distribution is indicative of the wide biological effects of the natriuretic peptides. Although ANP and BNP were initially characterized by their actions promoting diuresis and natriuresis, contributing to maintenance of extracellular fluid volume and vascular tone (114), they mediate actions beyond simply control of blood pressure and 
volume homeostasis. These include but are not limited to obesity and metabolic regulation, atherosclerotic and thrombotic control, and cardiac remodeling (115).

ANP and BNP are synthesized as precursor pro-hormones (proANP and proBNP) which are then processed to their biologically active forms ANP and BNP, and biologically inactive N-terminal proANP (NT-proANP) and NT-proBNP forms (116). Of these, BNP and NT-proBNP have demonstrated diagnostic and prognostic value in patients with HF (117). Increased BNP is independently associated with the increased risk of developing HF even within an asymptomatic general population (118) and once HF manifests, higher BNP levels are associated with increased risk of adverse events (119). Whereas, BNP and NT-ProBNP are elevated in clinical HF regardless of the LV $\mathrm{EF}$, these levels are usually higher in HFrEF than in HFpEF (120, 121). Circulating BNP levels are also typically lower in patients with obesity compared to normal weight counterparts given a similar degree of clinical HF. This is evident in HFpEF, where obese patients with HFpEF usually have lower circulating BNP and NT-ProBNP levels than non-obese patients $(24,122)$. However, despite the reduced levels of natriuretic peptides in obese patients, they still serve as an important tool in HF both for screening and prognostic purposes, albeit at a lower threshold $(93,123,124)$. Obesity in mice and rats is associated with a reduction in natriuretic peptides levels $(125,126)$, even in the setting of impaired cardiac function (127).

\section{The Natriuretic Handicap}

The inverse relationship between circulating cardiac BNP and obesity (defined by BMI) is termed the "natriuretic handicap" and has been described in both healthy subjects and patients with HF $(31,128)$. It has been hypothesized that BNP levels are reduced in obesity due to the differential expression of their clearance receptor (NPRC) resulting in enhanced degradation in adipose tissue (129). Additionally, others showed that obese patients have decreased natriuretic peptides production (130, 131); consistent with pre-clinical studies in murine obesity models showing reduced levels of natriuretic peptides cardiac mRNA expression $(126,132)$. Other mechanisms linking natriuretic peptides reduction and insulin resistance have also been proposed to explain this inverse relationship $(133,134)$. ANP and BNP can be also degraded by extracellular proteases such as neprilysin $(116,135)$. Neprilysin is secreted by adipocytes and promotes adipogenesis, creating a positive feedback loop. People with obesity have increased levels of neprilysin in proportion with their body mass (136) and neprilysin levels are particularly elevated in obese patients with HFpEF (137). NT-proBNP is mainly cleared by renal excretion and is not a substrate for neprilysin degradation (138). A recent phase II clinical trial investigated the effect of an angiotensin receptor neprilysin inhibitor (LCZ696) in overweight/obese HFpEF patients for 36 weeks and found left atrial reverse remodeling and improvement in NYHA class. These results were accompanied with a reduction in NT-proBNP suggesting that LCZ696 reduced left ventricular pressures and wall stress (139), and provided the rationale for an outcomes trial in HFpEF, which is presently underway (140).

\section{Cardiac Natriuretic Peptides Signaling in the Adipose Tissue}

White adipose tissue was previously thought to only function as an energy storage unit with limited metabolic activity, and human brown adipose tissue to be active only in infants before disappearing in childhood. It is now known that both, white and brown adipose tissues have in highly active roles in metabolic regulation (141-143). We and others recently showed that cardiac natriuretic peptide signaling causes alterations in energy expenditure and metabolism, and promotes brown adipose-like features in white adipose tissue depots (144-147) and that this is evident in HFpEF (146). Natriuretic peptide signaling is mediated predominantly through the binding of NPRA, which possesses intrinsic guanylyl cyclase activity. Conversely, NPRC serves primarily as the clearance receptor, sequestering natriuretic peptides from the circulation for internalization and subsequent degradation (112). Thus, the ratio of NPRA to NPRC is an important regulator of overall natriuretic peptide activity (148). Upon binding of natriuretic peptides to NPRA in the adipocyte, the receptor's guanylyl cyclase is activated, producing cGMP, which then activates intracellular PKG (112, 149). PKG phosphorylates several lipolytic proteins, including hormone-sensitive lipase (HSL), perilipin, and adipose triglyceride lipase (ATGL), resulting in the breakdown of stored lipids into free fatty acids. In parallel, PKG phosphorylates p38MAPK, which modulates the brown-fat thermogenic program by increasing transcription of proteins such as uncoupling protein-1 (UCP-1) and peroxisome proliferator activated receptor gamma coactivator 1 alpha (PGC-1 $\alpha)(146,149)$. UCP-1 is responsible for the uncoupling of oxidative phosphorylation and PGC$1 \alpha$ is the key regulator of oxidative metabolism $(141,150)$. UCP1 and PGC-1 $\alpha$ promote mitochondrial biogenesis and coupled and uncoupled respiration resulting in enhanced energy expenditure and thereby limiting adipose tissue expansion (110). Natriuretic peptide signaling in adipose tissue shares activity homology and similar potency with sympathetic activation via $\beta$-adrenergic receptors (145). Sympathetic stimulators, such as cold temperature, increase circulating catecholamines that bind to $\beta$-adrenergic receptors on adipose tissue (151-153). This increases PKA via a cAMP-dependent mechanism. PKA shares homology with PKG thus both sympathetic nervoussystem and natriuretic peptide signaling increase metabolic activity in adipose tissue by activating lipolysis, and modulating the brown-fat thermogenic program through p38-MAPK $(113,147,149)$ (Figure 1).

Metabolic disorders such as obesity and type 2 diabetes are associated with dysregulation of the natriuretic peptide system $(154,155)$. The natriuretic peptide receptor ratio in adipose tissue was inversely associated with obesity, glucose intolerance and insulin resistance in a cross-sectional analysis of subjects with a wide range of BMI and glucose tolerance (156). Insulin, which modulates blood glucose levels, exerts potent lipogenic effects, and is also an important regulator of natriuretic peptide activity. A low insulin fasting-state leads to an increase in NPRA mRNA and a decrease in NPRC mRNA whereas conversely, in hyperinsulinemic ob/ob 


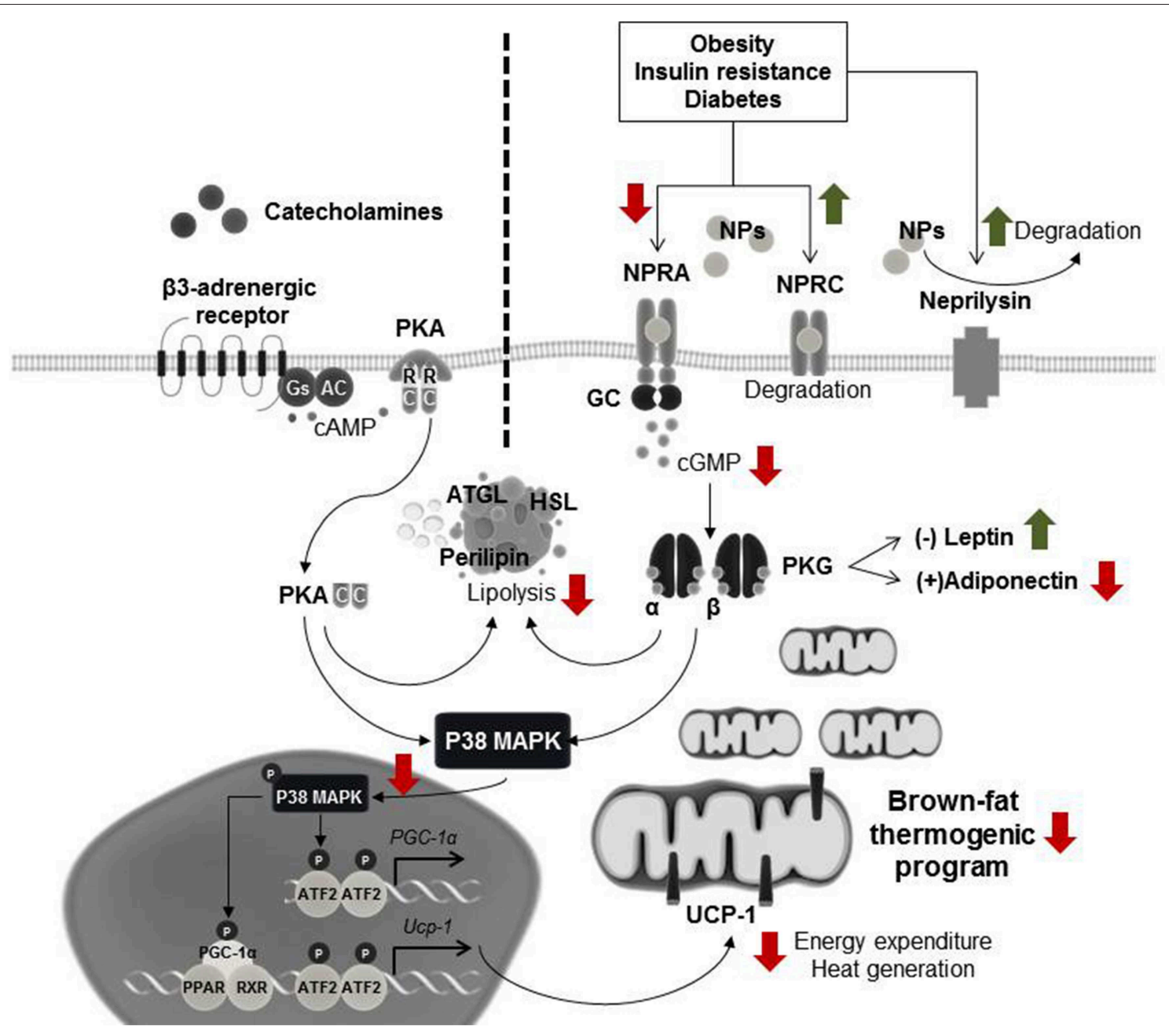

FIGURE 1 | Natriuretic peptide signaling in adipose tissue. Cardiac stress, such as HFpEF, induces increased natriuretic peptides levels. These natriuretic peptides bind to their receptor, natriuretic peptide active receptor (NPRA), in the adipocyte, and activate guanylyl cyclase (GC), increasing cGMP levels. Adipocytes also express natriuretic peptide clearance receptor (NPRC) that functions to remove natriuretic peptides from the circulation. The cGMP produced by NPRA-GC activates cGMP dependent protein kinase (PKG), which triggers a signaling cascade that results in enhanced lipolysis and activation of p38 mitogen-activated protein kinase (p38-MAPK), culminating in the transcription of uncoupling protein 1 (UCP-1) and inducing the brown fat thermogenic program. In parallel, other stimuli, such as cold exposure, can also induce this program via the $\beta$-adrenergic signaling pathway. Here catecholamines bind to the $\beta$-adrenergic receptor which activates adenylate cyclase (AC), producing CAMP. Binding of CAMP to the regulatory subunits $(\mathrm{R})$ of CAMP-dependent protein kinase (PKA) releases its catalytic subunits (C), which also activate lipolysis and induce p38-MAPK phosphorylation. During obesity, insulin resistance and diabetes, the natriuretic peptide signaling is diminished leading to a decrease in the browning thermogenic program. Red and green arrows represent the down-regulatory or up-regulatory effects that metabolic disorders have in this signaling pathway. To date, the combined effect that obesity and HFpEF would have in adipose tissue is unknown and needs further investigation.

mice, levels of NPRC mRNA are increased and levels of NPRA mRNA are decreased $(157,158)$. Similarly NPRA mRNA levels are lower in human adipocytes obtained from individuals with pre-diabetes and type 2 diabetes. Treatment with BNP also increases glucose uptake in adipose tissue independent of insulin levels. This is mediated via PKB phosphorylation and the mechanistic target of rapamycin complex (mTORC)1/2 activation, leading to translocation of glucose transporter 4 (GLUT4) to the cell membrane (159). Thus, insulin inhibits natriuretic peptides, while natriuretic peptides increase insulin sensitivity and help to control blood glucose levels.
There is also interplay between natriuretic petides released from the heart and adipokines released by adipose tissue. ANP decreases the secretion of leptin in cultured human subcutaneous adipose tissue (160) and isolated human adipocytes from obese individuals (161). An inverse relationship between circulating BNP and plasma levels of leptin also exists in HFrEF patients (162). Yet, adiponectin synthesis and secretion has been positively associated with natriuretic peptides. ANP acutely increased systemic levels of adiponectin in healthy subjects (163) and both, ANP and BNP, promoted the expression and secretion of adiponectin in human adipocytes in culture and in chronic HFrEF patients (164). These findings are also consistent 
with observational studies showing positive associations between circulating levels of adiponectin and BNP in healthy subjects without HF (165) and HFrEF patients (67). Thus, higher adiponectin levels tend to be associated with reduced LV systolic function in humans (166).

\section{CONCLUDING REMARKS}

HFpEF is a major public problem that is increasing in prevalence yet lacking in evidence-based therapies. A more tailored approach in $\mathrm{HFpEF}$ is needed to investigate the pathophysiological mechanisms that underlie this syndrome. Obesity-associated HFpEF is an important sub-phenotype of HFpEF, with evidence supporting crosstalk between the heart and the adipose tissue. Thus, the ability to modulate the signaling pathways that regulate adipose tissue and the heart in HFpEF

\section{REFERENCES}

1. Metra M, Teerlink JR. Heart failure. Lancet. (2017) 390:1981-95. doi: 10.1016/S0140-6736(17)31071-1

2. Ponikowski P, Voors AA, Anker SD, Bueno H, Cleland JG, Coats AJ, et al. 2016 ESC Guidelines for the diagnosis and treatment of acute and chronic heart failure: the Task Force for the diagnosis and treatment of acute and chronic heart failure of the European Society of Cardiology (ESC). Developed with the special contribution of the Heart Failure Association (HFA) of the ESC. Eur J Heart Fail. (2016) 37:2129-200. doi: 10.1093/eurheartj/ehw128

3. Benjamin EJ, Muntner P, Alonso A, Bittencourt MS, Callaway CW, Carson AP, et al. Heart disease and stroke statistics-2019 update: a report from the American Heart Association. Circulation. (2019) 139:e56-28. doi: 10.1161/CIR.0000000000000659

4. Heidenreich PA, Albert NM, Allen LA, Bluemke DA, Butler J, Fonarow GC, et al. Forecasting the impact of heart failure in the United States: a policy statement from the American Heart Association. Circ Heart Fail. (2013) 6:606-19. doi: 10.1161/HHF.0b013e318291329a

5. Paulus WJ, Tschope C. A novel paradigm for heart failure with preserved ejection fraction: comorbidities drive myocardial dysfunction and remodeling through coronary microvascular endothelial inflammation. J Am Coll Cardiol. (2013) 62:263-71. doi: 10.1016/j.jacc.2013.02.092

6. Sanderson JE. HFNEF, HFpEF, HF-PEF, or DHF: what is in an acronym? JACC Heart Fail. (2014) 2:93-4. doi: 10.1016/j.jchf.2013.09.006

7. McMurray JJ. Clinical practice. Systolic heart failure. N Engl J Med. (2010) 362:228-38. doi: 10.1056/NEJMcp0909392

8. Redfield MM. Heart failure with preserved ejection fraction. $N$ Engl J Med. (2016) 375:1868-77. doi: 10.1056/NEJMcp1511175

9. Sanderson JE. Heart failure with a normal ejection fraction. Heart. (2007) 93:155-8. doi: 10.1136/hrt.2005.074187

10. Beale AL, Meyer P, Marwick TH, Lam CSP, Kaye DM. Sex Differences in cardiovascular pathophysiology: why women are overrepresented in heart failure with preserved ejection fraction. Circulation. (2018) 138:198-205. doi: 10.1161/CIRCULATIONAHA.118.034271

11. Hunt SA, Baker DW, Chin MH, Cinquegrani MP, Feldman AM, Francis GS, et al. ACC/AHA guidelines for the evaluation and management of chronic heart failure in the adult: executive summary. A report of the American College of Cardiology/American Heart Association Task Force on Practice Guidelines (Committee to revise the 1995 Guidelines for the Evaluation and Management of Heart Failure). J Am Coll Cardiol. (2001) 104:2996-3007. doi: $10.1161 /$ hc 4901.102568

12. McMurray J, Pfeffer MA. New therapeutic options in congestive heart failure: Part II. Circulation. (2002) 105:2223-8. doi: 10.1161/01.CIR.0000014771.38666.22 might have clinical implications and be translated into effective therapies for HFpEF, particularly obesity-associated HFpEF.

\section{AUTHOR CONTRIBUTIONS}

FS and MV-M discussed and conceived the outline of the manuscript. AO, RO, and MV-M drafted the initial version of the manuscript. FS and MV-M reviewed the manuscript. All authors approved the final version of the manuscript.

\section{FUNDING}

This work was funded in part by federal funds from the NIH (HL117153 and HL145985 to FS). MV-M was supported by a postdoctoral fellowship from the American Heart Association (17POST33660439).

13. Tan YT, Wenzelburger F, Lee E, Heatlie G, Leyva F, Patel K, et al. The pathophysiology of heart failure with normal ejection fraction: exercise echocardiography reveals complex abnormalities of both systolic and diastolic ventricular function involving torsion, untwist, and longitudinal motion. J Am Coll Cardiol. (2009) 54:36-46. doi: 10.1016/j.jacc.2009.03.037

14. Borlaug BA, Olson TP, Lam CS, Flood KS, Lerman A, Johnson $\mathrm{BD}$, et al. Global cardiovascular reserve dysfunction in heart failure with preserved ejection fraction. J Am Coll Cardiol. (2010) 56:845-54. doi: 10.1016/j.jacc.2010.03.077

15. Prasad A, Hastings JL, Shibata S, Popovic ZB, Arbab-Zadeh A, Bhella PS, et al. Characterization of static and dynamic left ventricular diastolic function in patients with heart failure with a preserved ejection fraction. Circ Heart Fail. (2010) 3:617-26. doi: 10.1161/CIRCHEARTFAILURE.109.867044

16. Sharma K, Kass DA. Heart failure with preserved ejection fraction: mechanisms, clinical features, and therapies. Circ Res. (2014) 115:79-96. doi: 10.1161/CIRCRESAHA.115.302922

17. Yancy CW, Jessup M, Bozkurt B, Butler J, Casey DE, Jr, Colvin MM, et al. 2017 ACC/AHA/HFSA Focused Update of the 2013 ACCF/AHA guideline for the management of heart failure: a report of the American College of Cardiology/American Heart Association Task Force on clinical practice guidelines and the heart failure society of America. J Am Coll Cardiol. (2017) 136:e137-61. doi: 10.1161/CIR.0000000000000509

18. Roh J, Houstis N, Rosenzweig A. Why don't we have proven treatments for HFpEF? Circ Res. (2017) 120:1243-5. doi: 10.1161/CIRCRESAHA.116.310119

19. Shah SJ, Katz DH, Selvaraj S, Burke MA, Yancy CW, Gheorghiade $\mathrm{M}$, et al. Phenomapping for novel classification of heart failure with preserved ejection fraction. Circulation. (2015) 131:269-79. doi: 10.1161/CIRCULATIONAHA.114.010637

20. Shah SJ, Kitzman DW, Borlaug BA, van HL, Zile MR, Kass DA, et al. Phenotype-specific treatment of heart failure with preserved ejection fraction: a multiorgan roadmap. Circulation. (2016) 134:73-90. doi: 10.1161/CIRCULATIONAHA.116.021884

21. Borlaug BA. The pathophysiology of heart failure with preserved ejection fraction. Nat Rev Cardiol. (2014) 11:507-15. doi: 10.1038/nrcardio.2014.83

22. Kitzman DW, Shah SJ. The HFpEF obesity phenotype: the elephant in the room. J Am Coll Cardiol. (2016) 68:200-3. doi: 10.1016/j.jacc.2016. 05.019

23. Kenchaiah S, Evans JC, Levy D, Wilson PW, Benjamin EJ, Larson MG, et al. Obesity and the risk of heart failure. N Engl J Med. (2002) 347:305-13. doi: 10.1056/NEJMoa020245

24. Obokata M, Reddy YNV, Pislaru SV, Melenovsky V, Borlaug BA. Evidence Supporting the existence of a distinct obese phenotype of heart failure with preserved ejection fraction. Circulation. (2017) 136:6-19. doi: 10.1161/CIRCULATIONAHA.116.026807 
25. Tsujimoto T, Kajio H. Abdominal Obesity is associated with an increased risk of all-cause mortality in patients with HFpEF. $J$ Am Coll Cardiol. (2017) 70:2739-49. doi: 10.1016/j.jacc.2017.0 9.1111

26. Haass M, Kitzman DW, Anand IS, Miller A, Zile MR, Massie BM, et al. Body mass index and adverse cardiovascular outcomes in heart failure patients with preserved ejection fraction: results from the Irbesartan in Heart Failure with Preserved Ejection Fraction (I-PRESERVE) trial. Circ Heart Fail. (2011) 4:324-31. doi: 10.1161/CIRCHEARTFAILURE.110.959890

27. Redfield MM, Chen HH, Borlaug BA, Semigran MJ, Lee KL, Lewis G, et al. Effect of phosphodiesterase- 5 inhibition on exercise capacity and clinical status in heart failure with preserved ejection fraction: a randomized clinical trial. JAMA. (2013) 309:1268-77.

28. Anjan VY, Loftus TM, Burke MA, Akhter N, Fonarow GC, Gheorghiade M, et al. Prevalence, clinical phenotype, and outcomes associated with normal B-type natriuretic peptide levels in heart failure with preserved ejection fraction. Am J Cardiol. (2012) 110:870-6. doi: 10.1016/j.amjcard.2012.05.014

29. Caruana L, Petrie MC, Davie AP, McMurray JJ. Do patients with suspected heart failure and preserved left ventricular systolic function suffer from "diastolic heart failure" or from misdiagnosis? A prospective descriptive study. BMJ. (2000) 321:215-8. doi: 10.1136/bmj.321.7255.215

30. Savji N, Meijers WC, Bartz TM, Bhambhani V, Cushman M, Nayor $\mathrm{M}$, et al. The Association of Obesity and Cardiometabolic Traits With Incident HFpEF and HFrEF. JACC Heart Fail. (2018) 6:701-9. doi: 10.1016/j.jchf.2018.05.018

31. Clerico A, Zaninotto M, Passino C, Plebani M. Obese phenotype and natriuretic peptides in patients with heart failure with preserved ejection fraction. Clin Chem Lab Med. (2018) 56:1015-25. doi: $10.1515 / \mathrm{cclm}-2017-0840$

32. Bostick B, Habibi J, DeMarco VG, Jia G, Domeier TL, Lambert MD, et al. Mineralocorticoid receptor blockade prevents Western diet-induced diastolic dysfunction in female mice. Am J Physiol Heart Circ Physiol. (2015) 308:H1126-H1135. doi: 10.1152/ajpheart.00898.2014

33. Martinez-Martinez E, Jurado-Lopez R, Valero-Munoz M, Bartolome MV, Ballesteros S, Luaces $\mathrm{M}$, et al. Leptin induces cardiac fibrosis through galectin-3, mTOR and oxidative stress: potential role in obesity. J Hypertens. (2014) 32:1104-14. doi: 10.1097/HJH.0000000000000149

34. Alex L, Russo I, Holoborodko V, Frangogiannis NG. Characterization of a mouse model of obesity-related fibrotic cardiomyopathy that recapitulates features of human heart failure with preserved ejection fraction. Am J Physiol Heart Circ Physiol. (2018) 315:H934-49. doi: 10.1152/ajpheart.00238.2018

35. Liu Y, Li LN, Guo S, Zhao XY, Liu YZ, Liang C, et al. Melatonin improves cardiac function in a mouse model of heart failure with preserved ejection fraction. Redox Biol. (2018) 18:211-21. doi: 10.1016/j.redox.2018.07.007

36. Bowen TS, Brauer D, Rolim NPL, Baekkerud FH, Kricke A, Ormbostad Berre $\mathrm{AM}$, et al. Exercise training reveals inflexibility of the diaphragm in an animal model of patients with obesity-driven heart failure with a preserved ejection fraction. J Am Heart Assoc. (2017) 6:e006416. doi: 10.1161/JAHA.117.006416

37. Schmederer Z, Rolim N, Bowen TS, Linke A, Wisloff U, Adams V. Endothelial function is disturbed in a hypertensive diabetic animal model of HFpEF: moderate continuous vs. high intensity interval training. Int $J$ Cardiol. (2018) 273:147-54. doi: 10.1016/j.ijcard.2018.08.087

38. Meng Q, Lai YC, Kelly NJ, Bueno M, Baust JJ, Bachman TN, et al. Development of a mouse model of metabolic syndrome, pulmonary hypertension, and heart failure with preserved ejection fraction. Am J Respir Cell Mol Biol. (2017) 56:497-505. doi: 10.1165/rcmb.2016-0177OC

39. Valero-Munoz M, Backman W, Sam F. Murine models of heart failure with preserved ejection fraction: a "Fishing Expedition". JACC Basic Transl Sci. (2017) 2:770-89. doi: 10.1016/j.jacbts.2017.07.013

40. Turer AT, Hill JA, Elmquist JK, Scherer PE. Adipose tissue biology and cardiomyopathy: translational implications. Circ Res. (2012) 111:1565-77. doi: 10.1161/CIRCRESAHA.111.262493

41. Massie BM. Obesity and heart failure-risk factor or mechanism? N Engl J Med. (2002) 347:358-9. doi: 10.1056/NEJMe020065

42. Packer M. Leptin-aldosterone-neprilysin axis: identification of its distinctive role in the pathogenesis of the three phenotypes of heart failure in people with obesity. Circulation. (2018) 137:1614-31. doi: 10.1161/CIRCULATIONAHA.117.032474
43. Alpert MA, Lavie CJ, Agrawal H, Aggarwal KB, Kumar SA. Obesity and heart failure: epidemiology, pathophysiology, clinical manifestations, and management. Transl Res. (2014) 164:345-56. doi: 10.1016/j.trsl.2014.04.010

44. Packer M, Kitzman DW. Obesity-Related Heart Failure With a Preserved Ejection Fraction: The mechanistic rationale for combining inhibitors of aldosterone, neprilysin, and sodium-glucose cotransporter-2. JACC Heart Fail. (2018) 6:633-9. doi: 10.1016/j.jchf.2018.01.009

45. Akoumianakis I, Antoniades C. The interplay between adipose tissue and the cardiovascular system: is fat always bad? Cardiovasc Res. (2017) 113:9991008. doi: $10.1093 / \mathrm{cvr} / \mathrm{cvx} 111$

46. Kershaw EE, Flier JS. Adipose tissue as an endocrine organ. J Clin Endocrinol Metab. (2004) 89:2548-56. doi: 10.1210/jc.2004-0395

47. Correia ML, Morgan DA, Sivitz WI, Mark AL, Haynes WG. Leptin acts in the central nervous system to produce dose-dependent changes in arterial pressure. Hypertension. (2001) 37:936-42. doi: 10.1161/01.HYP.37.3.936

48. Fruhbeck G. Intracellular signalling pathways activated by leptin. Biochem J. (2006) 393(Pt 1):7-20. doi: 10.1042/BJ20051578

49. Faulkner JL, Bruder-Nascimento T, Belin de Chantemele EJ. The regulation of aldosterone secretion by leptin: implications in obesityrelated cardiovascular disease. Curr Opin Nephrol Hypertens. (2018) 27:63-9. doi: 10.1097/MNH.0000000000000384

50. Xie D, Bollag WB. Obesity, hypertension and aldosterone: is leptin the link? J Endocrinol. (2016) 230:F7-F11. doi: 10.1530/JOE-16-0160

51. Vatutin NT, Shevelok AN. Relationship between blood aldosterone and somatometric parameters in patients with chronic heart failure and preserved ejection fraction of left ventricle. Klin Med. (2016) 94:265-9.

52. Olivier A, Pitt B, Girerd N, Lamiral Z, Machu JL, McMurray JJV, et al. Effect of eplerenone in patients with heart failure and reduced ejection fraction: potential effect modification by abdominal obesity. Insight from the EMPHASIS-HF trial. Eur J Heart Fail. (2017) 19:1186-97. doi: 10.1002/ejhf.792

53. Kotlyar E, Vita JA, Winter MR, Awtry EH, Siwik DA, Keaney JF, Jr, et al. The relationship between aldosterone, oxidative stress, and inflammation in chronic, stable human heart failure. J Card Fail. (2006) 12:122-7. doi: 10.1016/j.cardfail.2005.08.005

54. Shieh FK, Kotlyar E, Sam F. Aldosterone and cardiovascular remodelling: focus on myocardial failure. J Renin Angiotensin Aldosterone Syst. (2004) 5:3-13. doi: $10.3317 /$ jraas.2004.005

55. Na T, Dai DZ, Tang XY, Dai Y. Upregulation of leptin pathway correlates with abnormal expression of SERCA2a, phospholamban and the endothelin pathway in heart failure and reversal by CPU86017. Naunyn Schmiedebergs Arch Pharmacol. (2007) 375:39-49. doi: 10.1007/s00210-007-0134-1

56. Van den Bergh A, Vanderper A, Vangheluwe P, Desjardins F, Nevelsteen I, Verreth W, et al. Dyslipidaemia in type II diabetic mice does not aggravate contractile impairment but increases ventricular stiffness. Cardiovasc Res. (2008) 77:371-9. doi: 10.1093/cvr/cvm001

57. Sam F, Walsh K. What can adiponectin say about left ventricular function? Heart. (2010) 96:331-2. doi: 10.1136/hrt.2009.178590

58. Engeli S, Feldpausch M, Gorzelniak K, Hartwig F, Heintze U, Janke J, et al. Association between adiponectin and mediators of inflammation in obese women. Diabetes. (2003) 52:942-7. doi: 10.2337/diabetes.52.4.942

59. Hong SJ, Park CG, Seo HS, Oh DJ, Ro YM. Associations among plasma adiponectin, hypertension, left ventricular diastolic function and left ventricular mass index. Blood Press. (2004) 13:236-42. doi: 10.1080/08037050410021397

60. Francisco C, Neves JS, Falcao-Pires I, Leite-Moreira A. Can Adiponectin Help us to Target Diastolic Dysfunction? Cardiovasc Drugs Ther. (2016) 30:635-44. doi: 10.1007/s10557-016-6694-x

61. Ouchi N, Kihara S, Arita Y, Maeda K, Kuriyama H, Okamoto Y, et al. Novel modulator for endothelial adhesion molecules: adipocytederived plasma protein adiponectin. Circulation. (1999) 100:2473-6. doi: 10.1161/01.CIR.100.25.2473

62. Essick EE, Wilson RM, Pimentel DR, Shimano M, Baid S, Ouchi $\mathrm{N}$, et al. Adiponectin modulates oxidative stress-induced autophagy in cardiomyocytes. PLoS ONE. (2013) 8:e68697. doi: 10.1371/journal.pone.0068697

63. Essick EE, Ouchi N, Wilson RM, Ohashi K, Ghobrial J, Shibata R, et al. Adiponectin mediates cardioprotection in oxidative stress-induced cardiac 
myocyte remodeling. Am J Physiol Heart Circ Physiol. (2011) 301:H984-93. doi: 10.1152/ajpheart.00428.2011

64. Shibata R, Ouchi N, Ito M, Kihara S, Shiojima I, Pimentel DR, et al. Adiponectin-mediated modulation of hypertrophic signals in the heart. Nat Med. (2004) 10:1384-9. doi: 10.1038/nm1137

65. Ouchi N, Kobayashi H, Kihara S, Kumada M, Sato K, Inoue T, et al. Adiponectin stimulates angiogenesis by promoting cross-talk between AMPactivated protein kinase and Akt signaling in endothelial cells. J Biol Chem. (2004) 279:1304-9. doi: 10.1074/jbc.M310389200

66. Frankel DS, Vasan RS, D'Agostino RB, Sr., Benjamin EJ, Levy D, Wang TJ, et al. Resistin, adiponectin, and risk of heart failure the Framingham offspring study. J Am Coll Cardiol. (2009) 53:754-62. doi: 10.1016/j.jacc.2008.07.073

67. Kistorp C, Faber J, Galatius S, Gustafsson F, Frystyk J, Flyvbjerg A, et al. Plasma adiponectin, body mass index, and mortality in patients with chronic heart failure. Circulation. (2005) 112:1756-62. doi: 10.1161/CIRCULATIONAHA.104.530972

68. George J, Patal S, Wexler D, Sharabi Y, Peleg E, Kamari Y, et al. Circulating adiponectin concentrations in patients with congestive heart failure. Heart. (2006) 92:1420-4. doi: 10.1136/hrt.2005.083345

69. Tamura T, Furukawa Y, Taniguchi R, Sato Y, Ono K, Horiuchi H, et al. Serum adiponectin level as an independent predictor of mortality in patients with congestive heart failure. Circ J. (2007) 71:623-30. doi: 10.1253/circj. 71.623

70. Antoniades C, Antonopoulos AS, Tousoulis D, Stefanadis C. Adiponectin: from obesity to cardiovascular disease. Obes Rev. (2009) 10:269-79. doi: 10.1111/j.1467-789X.2009.00571.x

71. Behre CJ. Adiponectin: saving the starved and the overfed. Med Hypotheses. (2007) 69:1290-2. doi: 10.1016/j.mehy.2007.02.044

72. Biolo A, Shibata R, Ouchi N, Kihara S, Sonoda M, Walsh $\mathrm{K}$, et al. Determinants of adiponectin levels in patients with chronic systolic heart failure. Am J Cardiol. (2010) 105:1147-52. doi: 10.1016/j.amjcard.2009.12.015

73. Norvik JV, Schirmer H, Ytrehus K, Jenssen TG, Zykova SN, Eggen AE, et al. Low adiponectin is associated with diastolic dysfunction in women: a crosssectional study from the Tromso Study. BMC Cardiovasc Disord. (2017) 17:79. doi: 10.1186/s12872-017-0509-2

74. Sam F, Duhaney TA, Sato K, Wilson RM, Ohashi K, Sono-Romanelli S, et al. Adiponectin deficiency, diastolic dysfunction, and diastolic heart failure. Endocrinology. (2010) 151:322-31. doi: 10.1210/en.2009-0806

75. Tanaka K, Wilson RM, Essick EE, Duffen JL, Scherer PE, Ouchi N, et al. Effects of adiponectin on calcium-handling proteins in heart failure with preserved ejection fraction. Circ Heart Fail. (2014) 7:976-85. doi: 10.1161/CIRCHEARTFAILURE.114.001279

76. Fuster JJ, Ouchi N, Gokce N, Walsh K. Obesity-induced changes in adipose tissue microenvironment and their impact on cardiovascular disease. Circ Res. (2016) 118:1786-807. doi: 10.1161/CIRCRESAHA.115.306885

77. Schiattarella GG, Altamirano F, Tong D, French KM, Villalobos E, Kim SY, et al. Nitrosative stress drives heart failure with preserved ejection fraction. Nature. (2019) 568:351-6. doi: 10.1038/s41586-019-1100-z

78. Chirinos JA, Zamani P. The Nitrate-Nitrite-NO Pathway and its implications for heart failure and preserved ejection fraction. Curr Heart Fail Rep. (2016) 13:47-59. doi: 10.1007/s11897-016-0277-9

79. Alvarez P, Briasoulis A. Immune modulation in heart failure: the promise of novel biologics. Curr Treat Options Cardiovasc Med. (2018) 20:26. doi: 10.1007/s11936-018-0617-z

80. Hulsmans M, Sager HB, Roh JD, Valero-Munoz M, Houstis NE, Iwamoto Y, et al. Cardiac macrophages promote diastolic dysfunction. J Exp Med. (2018) 215:423-40. doi: 10.1084/jem.20171274

81. Van Tassell BW, Trankle CR, Canada JM, Carbone S, Buckley L, Kadariya D, et al. IL-1 blockade in patients with heart failure with preserved ejection fraction. Circ Heart Fail. (2018) 11:e005036. doi: 10.1161/CIRCHEARTFAILURE. 118.005036

82. Van Tassell BW, Buckley LF, Carbone S, Trankle CR, Canada JM, Dixon DL, et al. Interleukin-1 blockade in heart failure with preserved ejection fraction: rationale and design of the Diastolic Heart Failure Anakinra Response Trial 2 (D-HART2). Clin Cardiol. (2017) 40:626-32. doi: 10.1002/clc. 22719
83. Upadhya B, Haykowsky MJ, Eggebeen J, Kitzman DW. Exercise intolerance in heart failure with preserved ejection fraction: more than a heart problem. J Geriatr Cardiol. (2015) 12:294-304. doi: 10.1007/s11897-015-0257-5

84. Houstis NE, Eisman AS, Pappagianopoulos PP, Wooster L, Bailey CS, Wagner PD, et al. Exercise intolerance in heart failure with preserved ejection fraction: diagnosing and ranking its causes using personalized O2 pathway analysis. Circulation. (2018) 137:148-61. doi: 10.1161/CIRCULATIONAHA.117.029058

85. Wolfel EE. Exploring the mechanisms of exercise intolerance in patients with HFpEF: are we too "Cardiocentric?". JACC Heart Fail. (2016) 4:646-8. doi: 10.1016/j.jchf.2016.06.002

86. Carbone S, Canada JM, Buckley LF, Trankle CR, Dixon DL, Buzzetti $\mathrm{R}$, et al. Obesity contributes to exercise intolerance in heart failure with preserved ejection fraction. J Am Coll Cardiol. (2016) 68:2487-8. doi: 10.1016/j.jacc.2016.08.072

87. Haykowsky MJ, Nicklas BJ, Brubaker PH, Hundley WG, Brinkley TE, Upadhya B, et al. Regional adipose distribution and its relationship to exercise intolerance in older obese patients who have heart failure with preserved ejection fraction. JACC Heart Fail. (2018) 6:640-9. doi: 10.1016/j.jchf.2018.06.002

88. Kokkinos P, Faselis C, Franklin B, Lavie CJ, Sidossis L, Moore H, et al. Cardiorespiratory fitness, body mass index and heart failure incidence. Eur $J$ Heart Fail. (2019) 21:436-44. doi: 10.1002/ejhf.1433

89. Kitzman DW, Brubaker PH, Morgan TM, Stewart KP, Little WC. Exercise training in older patients with heart failure and preserved ejection fraction: a randomized, controlled, single-blind trial. Circ Heart Fail. (2010) 3:659-67. doi: 10.1161/CIRCHEARTFAILURE.110.958785

90. Kitzman DW, Brubaker PH, Herrington DM, Morgan TM, Stewart KP, Hundley WG, et al. Effect of endurance exercise training on endothelial function and arterial stiffness in older patients with heart failure and preserved ejection fraction: a randomized, controlled, single-blind trial. J Am Coll Cardiol. (2013) 62:584-92. doi: 10.1016/j.jacc.2013.04.033

91. Edelmann F, Gelbrich G, Dungen HD, Frohling S, Wachter R, Stahrenberg $\mathrm{R}$, et al. Exercise training improves exercise capacity and diastolic function in patients with heart failure with preserved ejection fraction: results of the Ex-DHF (Exercise training in Diastolic Heart Failure) pilot study. J Am Coll Cardiol. (2011) 58:1780-91. doi: 10.1016/j.jacc.2011.06.054

92. Kitzman DW, Brubaker P, Morgan T, Haykowsky M, Hundley G, Kraus WE, et al. Effect of Caloric restriction or aerobic exercise training on peak oxygen consumption and quality of life in obese older patients with heart failure with preserved ejection fraction: a randomized clinical trial. JAMA. (2016) 315:36-46. doi: 10.1001/jama.2015.17346

93. Prenner SB, Mather PJ. Obesity and heart failure with preserved ejection fraction: a growing problem. Trends Cardiovasc Med. (2018) 28:322-7. doi: $10.1016 /$ j.tcm.2017.12.003

94. Lavie CJ, Alpert MA, Arena R, Mehra MR, Milani RV, Ventura HO. Impact of obesity and the obesity paradox on prevalence and prognosis in heart failure. JACC Heart Fail. (2013) 1:93-102. doi: 10.1016/j.jchf.2013. 01.006

95. Oreopoulos A, Padwal R, Kalantar-Zadeh K, Fonarow GC, Norris CM, McAlister FA. Body mass index and mortality in heart failure: a metaanalysis. Am Heart J. (2008) 156:13-22. doi: 10.1016/j.ahj.2008.02.014

96. Horwich TB, Fonarow GC, Hamilton MA, MacLellan WR, Woo MA, Tillisch JH. The relationship between obesity and mortality in patients with heart failure. J Am Coll Cardiol. (2001) 38:789-95. doi: 10.1016/S0735-1097(01)01448-6

97. Lissin LW, Gauri AJ, Froelicher VF, Ghayoumi A, Myers J, Giacommini J. The prognostic value of body mass index and standard exercise testing in male veterans with congestive heart failure. J Card Fail. (2002) 8:206-15. doi: $10.1054 /$ jcaf.2002.126812

98. Powell-Wiley TM, Ngwa J, Kebede S, Lu D, Schulte PJ, Bhatt DL, et al. Impact of body mass index on heart failure by race/ethnicity from the get with The Guidelines-Heart Failure (GWTG-HF) Registry. JACC Heart Fail. (2018) 6:233-42. doi: 10.1016/j.jchf.2017.11.011

99. Padwal R, McAlister FA, McMurray JJ, Cowie MR, Rich M, Pocock S, et al. The obesity paradox in heart failure patients with preserved versus reduced ejection fraction: a meta-analysis of individual patient data. Int J Obes. (2014) 38:1110-4. doi: $10.1038 /$ ijo.2013.203 
100. Kenchaiah S, Pocock SJ, Wang D, Finn PV, Zornoff LA, Skali H, et al. Body mass index and prognosis in patients with chronic heart failure: insights from the Candesartan in Heart failure: Assessment of Reduction in Mortality and morbidity (CHARM) program. Circulation. (2007) 116:62736. doi: 10.1161/CIRCULATIONAHA.106.679779

101. Kapoor JR, Heidenreich PA. Obesity and survival in patients with heart failure and preserved systolic function: a U-shaped relationship. Am Heart J. (2010) 159:75-80. doi: 10.1016/j.ahj.2009.10.026

102. Adamopoulos C, Meyer P, Desai RV, Karatzidou K, Ovalle F, White M, et al. Absence of obesity paradox in patients with chronic heart failure and diabetes mellitus: a propensity-matched study. Eur J Heart Fail. (2011) 13:200-6. doi: 10.1093/eurjhf/hfq159

103. Pozzo J, Fournier P, Lairez O, Vervueren PL, Delmas C, Elbaz M, et al. Obesity paradox: origin and best way to assess severity in patients with systolic HF. Obesity. (2015) 23:2002-8. doi: 10.1002/oby.21216

104. Vest AR, Wu Y, Hachamovitch R, Young JB, Cho L. The heart failure overweight/obesity survival paradox: the missing sex link. JACC Heart Fail. (2015) 3:917-26. doi: 10.1016/j.jchf.2015.06.009

105. Horwich TB, Fonarow GC, Clark AL. Obesity and the obesity paradox in heart failure. Prog Cardiovasc Dis. (2018) 61:151-6. doi: 10.1016/j.pcad.2018.05.005

106. Nagarajan V, Kohan L, Holland E, Keeley EC, Mazimba S. Obesity paradox in heart failure: a heavy matter. ESC Heart Fail. (2016) 3:227-34. doi: $10.1002 /$ ehf2.12120

107. Carbone S, Lavie CJ, Arena R. Obesity and heart failure: focus on the obesity paradox. Mayo Clin Proc. (2017) 92:266-79. doi: 10.1016/j.mayocp.2016.11.001

108. Tadic M, Cuspidi C. Obesity and heart failure with preserved ejection fraction: a paradox or something else? Heart Fail Rev. (2019) 24:379-85. doi: 10.1007/s10741-018-09766-x

109. Wang TJ. The obesity paradox in heart failure: weighing the evidence. J Am Coll Cardiol. (2014) 64:2750-2. doi: 10.1016/j.jacc.2014.09.068

110. Gruden G, Landi A, Bruno G. Natriuretic peptides, heart, and adipose tissue: new findings and future developments for diabetes research. Diabetes Care. (2014) 37:2899-908. doi: 10.2337/dc14-0669

111. Stingo AJ, Clavell AL, Heublein DM, Wei CM, Pittelkow MR, Burnett JC, Jr. Presence of C-type natriuretic peptide in cultured human endothelial cells and plasma. Am J Physiol. (1992) 263(4 Pt 2):H1318-21. doi: 10.1152/ajpheart.1992.263.4.H1318

112. Potter LR, Abbey-Hosch S, Dickey DM. Natriuretic peptides, their receptors, and cyclic guanosine monophosphate-dependent signaling functions. Endocr Rev. (2006) 27:47-72. doi: 10.1210/er.2005-0014

113. Collins S. A heart-adipose tissue connection in the regulation of energy metabolism. Nat Rev Endocrinol. (2014) 10:157-63. doi: $10.1038 /$ nrendo.2013.234

114. Palmer BF, Clegg DJ. An emerging role of natriuretic peptides: igniting the fat furnace to fuel and warm the heart. Mayo Clin Proc. (2015) 90:1666-78. doi: 10.1016/j.mayocp.2015.08.006

115. Zois NE, Bartels ED, Hunter I, Kousholt BS, Olsen LH, Goetze JP. Natriuretic peptides in cardiometabolic regulation and disease. Nat Rev Cardiol. (2014) 11:403-12. doi: 10.1038/nrcardio.2014.64

116. McKie PM, Burnett JC, Jr. NT-proBNP: The gold standard biomarker in heart failure. J Am Coll Cardiol. (2016) 68:2437-9. doi: 10.1016/j.jacc.2016.10.001

117. Zile MR, Claggett BL, Prescott MF, McMurray JJ, Packer M, Rouleau JL, et al. Prognostic implications of changes in N-terminal pro-B-Type natriuretic peptide in patients with heart failure. J Am Coll Cardiol. (2016) 68:2425-36. doi: 10.1016/j.jacc.2016.09.931

118. Wang TJ, Larson MG, Levy D, Benjamin EJ, Leip EP, Omland T, et al. Plasma natriuretic peptide levels and the risk of cardiovascular events and death. $N$ Engl J Med. (2004) 350:655-63. doi: 10.1056/NEJMoa031994

119. Fonarow GC, Peacock WF, Phillips CO, Givertz MM, Lopatin M. Admission B-type natriuretic peptide levels and in-hospital mortality in acute decompensated heart failure. J Am Coll Cardiol. (2007) 49:1943-50. doi: 10.1016/j.jacc.2007.02.037

120. O’Donoghue M, Chen A, Baggish AL, Anwaruddin S, Krauser DG, Tung $\mathrm{R}$, et al. The effects of ejection fraction on N-terminal ProBNP and BNP levels in patients with acute CHF: analysis from the ProBNP Investigation of
Dyspnea in the Emergency Department (PRIDE) study. J Card Fail. (2005) 11(5 Suppl.):S9-14. doi: 10.1016/j.cardfail.2005.04.011

121. Januzzi JL, Jr. Natriuretic peptides, ejection fraction, and prognosis: parsing the phenotypes of heart failure. J Am Coll Cardiol. (2013) 61:1507-9. doi: $10.1016 /$ j.jacc.2013.01.039

122. Stavrakis S, Pakala A, Thomas J, Chaudhry MA, Thadani U. Obesity, brain natriuretic peptide levels and mortality in patients hospitalized with heart failure and preserved left ventricular systolic function. Am J Med Sci. (2013) 345:211-7. doi: 10.1097/MAJ.0b013e318271c012

123. Buckley LF, Canada JM, Del Buono MG, Carbone S, Trankle CR, Billingsley $\mathrm{H}$, et al. Low NT-proBNP levels in overweight and obese patients do not rule out a diagnosis of heart failure with preserved ejection fraction. ESC Heart Fail. (2018) 5:372-8. doi: 10.1002/ehf2.12235

124. Daniels LB, Clopton P, Bhalla V, Krishnaswamy P, Nowak RM, McCord J, et al. How obesity affects the cut-points for B-type natriuretic peptide in the diagnosis of acute heart failure. Results from the Breathing Not Properly Multinational Study. Am Heart J. (2006) 151:999-1005. doi: 10.1016/j.ahj.2005.10.011

125. Zhang H, Thoonen R, Yao V, Buys ES, Popovich J, Su YR, et al. Regulation of B-type natriuretic peptide synthesis by insulin in obesity in male mice. Exp Physiol. (2016) 101:113-23. doi: 10.1113/EP085091

126. Cabiati M, Raucci S, Liistro T, Belcastro E, Prescimone T, Caselli $\mathrm{C}$, et al. Impact of obesity on the expression profile of natriuretic peptide system in a rat experimental model. PLoS ONE. (2013) 8:e72959. doi: 10.1371/journal.pone.0072959

127. Bartels ED, Nielsen JM, Bisgaard LS, Goetze JP, Nielsen LB. Decreased expression of natriuretic peptides associated with lipid accumulation in cardiac ventricle of obese mice. Endocrinology. (2010) 151:5218-25. doi: 10.1210/en.2010-0355

128. Nishimura M, Brann A, Chang KW, Maisel AS. The confounding effects of non-cardiac pathologies on the interpretation of cardiac biomarkers. Curr Heart Fail Rep. (2018) 15:239-49. doi: 10.1007/s11897-0180398-4

129. Gentili A, Frangione MR, Albini E, Vacca C, Ricci MA, De VS, et al. Modulation of natriuretic peptide receptors in human adipose tissue: molecular mechanisms behind the "natriuretic handicap" in morbidly obese patients. Transl Res. (2017) 186:52-61. doi: 10.1016/j.trsl.201 7.06 .001

130. Shah Z, Wiley M, Sridhar AM, Masoomi R, Biria M, Lakkireddy D, et al. Inverse correlation of venous brain natriuretic peptide levels with body mass index is due to decreased production. Cardiology. (2017) 137:159-66. doi: $10.1159 / 000464111$

131. Mizuno Y, Harada E, Katoh D, Kashiwagi Y, Morikawa Y, Nakagawa $\mathrm{H}$, et al. Cardiac production of B-type natriuretic peptide is inversely related to the plasma level of free fatty acids in obese individuals possible involvement of the insulin resistance -. Endocr J. (2013) 60:87-95. doi: 10.1507/endocri.EJ12-0239

132. Plante E, Menaouar A, Danalache BA, Broderick TL, Jankowski M, Gutkowska J. Treatment with brain natriuretic peptide prevents the development of cardiac dysfunction in obese diabetic $\mathrm{db} / \mathrm{db}$ mice. Diabetologia. (2014) 57:1257-67. doi: 10.1007/s00125-014-3201-4

133. Khan AM, Cheng S, Magnusson M, Larson MG, Newton-Cheh C, McCabe EL, et al. Cardiac natriuretic peptides, obesity, and insulin resistance: evidence from two community-based studies. J Clin Endocrinol Metab. (2011) 96:3242-9. doi: 10.1210/jc.2011-1182

134. Moro C. Targeting cardiac natriuretic peptides in the therapy of diabetes and obesity. Expert Opin Ther Targets. (2016) 20:1445-52. doi: 10.1080/14728222.2016.1254198

135. Volpe M, Carnovali M, Mastromarino V. The natriuretic peptides system in the pathophysiology of heart failure: from molecular basis to treatment. Clin Sci. (2016) 130:57-77. doi: 10.1042/CS20150469

136. Standeven KF, Hess K, Carter AM, Rice GI, Cordell PA, Balmforth AJ, et al. Neprilysin, obesity and the metabolic syndrome. Int J Obes. (2011) 35:1031-40. doi: 10.1038/ijo.2010.227

137. Goliasch G, Pavo N, Zotter-Tufaro C, Kammerlander A, Duca F, Mascherbauer J, et al. Soluble neprilysin does not correlate with outcome in heart failure with preserved ejection fraction. Eur J Heart Fail. (2016) 18:89-93. doi: 10.1002/ejhf.435 
138. Weber M, Hamm C. Role of B-type natriuretic peptide (BNP) and NT-proBNP in clinical routine. Heart. (2006) 92:843-9. doi: 10.1136/hrt.2005.071233

139. Solomon SD, Zile M, Pieske B, Voors A, Shah A, Kraigher-Krainer E, et al. The angiotensin receptor neprilysin inhibitor LCZ696 in heart failure with preserved ejection fraction: a phase 2 double-blind randomised controlled trial. Lancet. (2012) 380:1387-95. doi: 10.1016/S0140-6736(12)61227-6

140. Solomon SD, Rizkala AR, Gong J, Wang W, Anand IS, Ge J, et al. Angiotensin receptor neprilysin inhibition in heart failure with preserved ejection fraction: rationale and design of the PARAGONHF Trial. JACC Heart Fail. (2017) 5:471-82. doi: 10.1016/j.jchf.2017. 04.013

141. Thoonen R, Hindle AG, Scherrer-Crosbie M. Brown adipose tissue: The heat is on the heart. Am J Physiol Heart Circ Physiol. (2016) 310:H1592-605. doi: 10.1152/ajpheart.00698.2015

142. Lee P, Swarbrick MM, Ho KK. Brown adipose tissue in adult humans: a metabolic renaissance. Endocr Rev. (2013) 34:413-38. doi: 10.1210/er.2012-1081

143. Bartelt A, Heeren J. Adipose tissue browning and metabolic health. Nat Rev Endocrinol. (2014) 10:24-36. doi: 10.1038/nrendo.2013.204

144. Bordicchia M, Liu D, Amri EZ, Ailhaud G, Dessi-Fulgheri P, Zhang C, et al. Cardiac natriuretic peptides act via p38 MAPK to induce the brown fat thermogenic program in mouse and human adipocytes. J Clin Invest. (2012) 122:1022-36. doi: 10.1172/JCI59701

145. Sengenes C, Berlan M, De Glisezinski I, Lafontan M, Galitzky J. Natriuretic peptides: a new lipolytic pathway in human adipocytes. FASEB J. (2000) 14:1345-51. doi: 10.1096/fasebj.14.10.1345

146. Valero-Munoz M, Li S, Wilson RM, Hulsmans M, Aprahamian T, Fuster JJ, et al. Heart failure with preserved ejection fraction induces beiging in adipose tissue. Circ Heart Fail. (2016) 9:e002724. doi: 10.1161/CIRCHEARTFAILURE.115.002724

147. Whittle AJ, Vidal-Puig A. NPs - heart hormones that regulate brown fat? J Clin Invest. (2012) 122:804-7. doi: 10.1172/JCI62595

148. Matsukawa N, Grzesik WJ, Takahashi N, Pandey KN, Pang S, Yamauchi $\mathrm{M}$, et al. The natriuretic peptide clearance receptor locally modulates the physiological effects of the natriuretic peptide system. Proc Natl Acad Sci USA. (1999) 96:7403-8. doi: 10.1073/pnas.96.13.7403

149. Lafontan M, Moro C, Berlan M, Crampes F, Sengenes C, Galitzky J. Control of lipolysis by natriuretic peptides and cyclic GMP. Trends Endocrinol Metab. (2008) 19:130-7. doi: 10.1016/j.tem.2007.11.006

150. Austin S, St-Pierre J. PGC1alpha and mitochondrial metabolism-emerging concepts and relevance in ageing and neurodegenerative disorders. J Cell Sci. (2012) 125(Pt 21):4963-71. doi: 10.1242/jcs.113662

151. Kooijman S, van den Heuvel JK, Rensen PCN. Neuronal control of brown fat activity. Trends Endocrinol Metab. (2015) 26:657-68. doi: 10.1016/j.tem.2015.09.008

152. Cannon B, Nedergaard J. Brown adipose tissue: function and physiological significance. Physiol Rev. (2004) 84:277-359. doi: 10.1152/physrev.00015.2003

153. Collins S, Sarzani R, Bordicchia M. Coordinate control of adipose 'browning' and energy expenditure by beta-adrenergic and natriuretic peptide signalling. Int $J$ Obes Suppl. (2014) 4(Suppl. 1):S17-20. doi: 10.1038/ijosup.2014.6

154. Wang TJ, Larson MG, Levy D, Benjamin EJ, Leip EP, Wilson PW, et al. Impact of obesity on plasma natriuretic peptide levels. Circulation. (2004) 109:594-600. doi: 10.1161/01.CIR.0000112582.16683.EA

155. Wang TJ, Larson MG, Keyes MJ, Levy D, Benjamin EJ, Vasan RS. Association of plasma natriuretic peptide levels with metabolic risk factors in ambulatory individuals. Circulation. (2007) 115:1345-53. doi: 10.1161/CIRCULATIONAHA.106.655142

156. Kovacova Z, Tharp WG, Liu D, Wei W, Xie H, Collins S, et al. Adipose tissue natriuretic peptide receptor expression is related to insulin sensitivity in obesity and diabetes. Obesity. (2016) 24:820-8. doi: 10.1002/oby.21418

157. Nakatsuji H, Maeda N, Hibuse T, Hiuge A, Hirata A, Kuroda Y, et al. Reciprocal regulation of natriuretic peptide receptors by insulin in adipose cells. Biochem Biophys Res Commun. (2010) 392:100-5. doi: 10.1016/j.bbrc.2010.01.008

158. Bordicchia M, Ceresiani M, Pavani M, Minardi D, Polito M, Wabitsch $\mathrm{M}$, et al. Insulin/glucose induces natriuretic peptide clearance receptor in human adipocytes: a metabolic link with the cardiac natriuretic pathway. Am J Physiol Regul Integr Comp Physiol. (2016) 311:R104-14. doi: 10.1152/ajpregu.00499.2015

159. Coue M, Barquissau V, Morigny P, Louche K, Lefort C, Mairal A, et al. Natriuretic peptides promote glucose uptake in a cGMPdependent manner in human adipocytes. Sci Rep. (2018) 8:1097. doi: 10.1038/s41598-018-19619-0

160. Moro C, Klimcakova E, Lolmede K, Berlan M, Lafontan M, Stich V, et al. Atrial natriuretic peptide inhibits the production of adipokines and cytokines linked to inflammation and insulin resistance in human subcutaneous adipose tissue. Diabetologia. (2007) 50:1038-47. doi: 10.1007/s00125-007-0614-3

161. Fain JN, Kanu A, Bahouth SW, Cowan GS, Lloyd HM. Inhibition of leptin release by atrial natriuretic peptide (ANP) in human adipocytes. Biochem Pharmacol. (2003) 65:1883-8. doi: 10.1016/S0006-2952(03)00154-0

162. Melenovsky V, Kotrc M, Borlaug BA, Marek T, Kovar J, Malek I, et al. Relationships between right ventricular function, body composition, and prognosis in advanced heart failure. J Am Coll Cardiol. (2013) 62:1660-70. doi: 10.1016/j.jacc.2013.06.046

163. Birkenfeld AL, Boschmann M, Engeli S, Moro C, Arafat AM, Luft FC, et al. Atrial natriuretic peptide and adiponectin interactions in man. PLoS ONE. (2012) 7:e43238. doi: 10.1371/journal.pone.0043238

164. Tsukamoto O, Fujita M, Kato M, Yamazaki S, Asano Y, Ogai A, et al. Natriuretic peptides enhance the production of adiponectin in human adipocytes and in patients with chronic heart failure. J Am Coll Cardiol. (2009) 53:2070-7. doi: 10.1016/j.jacc.2009.02.038

165. Neeland IJ, Winders BR, Ayers CR, Das SR, Chang AY, Berry JD, et al. Higher natriuretic peptide levels associate with a favorable adipose tissue distribution profile. J Am Coll Cardiol. (2013) 62:752-60. doi: 10.1016/j.jacc.2013.03.038

166. Karas MG, Benkeser D, Arnold AM, Bartz TM, Djousse L, Mukamal KJ, et al. Relations of plasma total and high-molecular-weight adiponectin to new-onset heart failure in adults $>/=65$ years of age (from the Cardiovascular Health study). Am J Cardiol. (2014) 113:328-34. doi: 10.1016/j.amjcard.2013.09.027

Conflict of Interest Statement: The authors declare that the research was conducted in the absence of any commercial or financial relationships that could be construed as a potential conflict of interest.

Copyright (C) 2019 Oh, Okazaki, Sam and Valero-Muñoz. This is an open-access article distributed under the terms of the Creative Commons Attribution License (CC $B Y)$. The use, distribution or reproduction in other forums is permitted, provided the original author(s) and the copyright owner(s) are credited and that the original publication in this journal is cited, in accordance with accepted academic practice. No use, distribution or reproduction is permitted which does not comply with these terms. 